\title{
Daya Dukung Dunia Industri Terhadap Pelaksanaan Praktik Kerja Industri (Prakerin) \\ (Studi kasus terhadap pelaksanaan Prakerin siswa SMKN 27 Jakarta)
}

\author{
Soeprijanto \\ Fakultas Teknik Universitas Negeri Jakarta, E-mail: soeprijanto_unj@yahoo.com
}

\begin{abstract}
Abstrak: Tujuan penelitian ini adalah untuk mengetahui seberapa besar daya dukung dunia industri terhadap prakerin siswa SMK Negeri 27 Jakarta dan sekaligus untuk memberikan gambaran yang jelas mengenai pelaksanaan prakerin yang dilakukan oleh SMKNegeri 27 Jakarta. Penelitian ini dilaksanakan di Industri mitra SMKN 27 Jakarta. Pengambilan data dilakukan pada bulan Juli - November 2007. Penelitian menggunakan metode survei, dengan populasi semua perusahaan yang telah menjalin kerja sama dengan SMKN 27 Jakarta. Jumlah Sampel penelitian 20 perusahaan mitra SMK 27 Jakarta. Pengambilan sampel dilakukan secara acak. Instrumen penelitian berbentuk kuisioner yang diisi melalui wawancara langsung pada industri sampel. Hasil penelitian menunjukkan bahwa: 1) Sebagian besar pimpinan industri mitra SMK 27 menyatakan sangat mendukung program praktik kerja industri di Perusahaan yang di pimpin; 2) Bentuk-bentuk dukungan yang diberikan Industri untuk siswa Prakerin meliputi: manjadikan Prakerin sebagai program tetap perusahaan, menerima siswa Prakerin lebih dari 5x (lima kali) dalam setahun, Industri mitra berinisiatif memberikan informasi kesempatan Prakerin kepada sekolah; dan 3) Pelaksanaan Prakerin di Industri mitra SMK 27 Jakarta telah terlaksana dengan baik hal ini ditunjukan dengan adanya: penempatan siswa sesuai dengan bidang keahliannya, adanya bimbingan dari pihak Industri, Pemberian kesempatan kepada Sekolah untuk memonitor pelaksanaan praktik industri, Pemberian kesempatan kepada siswa untuk kerja sendiri, dan pihak Industri melakukan evaluasi, serta memberi sertifikat.
\end{abstract}

Kata kunci: keterkaitan dan kesepadanan, pendidikan sistem ganda, dan praktik kerja industri

\begin{abstract}
The purpose of this research is to find supporting capacity of the industry to the field work of SMK Negeri 27 Jakarta students and also to provide a clear picture of how SMK Negeri 27 Jakarta has performed the apprentice program. This research was conducted at SMK 27 Jakarta Industrial partners Data collecting was conducted in July-November 2007 from 20 industrial partners who were randomly selected. Executives of these industrial partners were interviewed and the result indicated that: (1) Majority of industrial partners executives were in favor of the apprentice program (2) Their support materialized in: making apprentice program a permanent one in their company, conducting apprentice program in 5 batches each year to accommodate more students, actively inform schools of such apprentice opportunities (3) apprentice programs in those industrial partners have been performing well as indicated by: student placement by their expertise, supervisory and guidance from assigned officer where the apprentice took place, allowing school to monitor the implementation of industrial apprenticeship and allowing apprentice students to work by themselves, evaluation and certificates issued by company at the end of apprenticeship.
\end{abstract}

Key words: link and match, dual system, and apprentice

\section{Pendahuluan}

Pemahaman terhadap suatu kerja sama baik dalam arti statis maupun dinamis bukan merupakan pekerjaan yang mudah, terutama pada waktu sekarang ini. Di sisi lain, perkembangan dunia industri semakin maju sehingga persaingan antar perusahaan semakin ketat.
Perusahaan tidak hanya dituntut untuk mendapatkan keuntungan yang maksimal namun juga diharapkan dapat berperan serta dalam meningkatkan pelayanan dan kerja sama dengan masyarakat dengan tujuan peningkatan kesejahteraan dan pendidikan terutama pada lingkungan sekitarnya. 
SMK Negeri 27 Jakarta merupakan salah satu lembaga pendidikan yang sangat diperlukan kehadirannya bagi masyarakat Indonesia sebagai penyedia generasi unggul calon tenaga kerja tingkat menengah bagi masyarakat kaitannya dengan bidang busana. Untuk menghadapi dunia yang semakin kompleks dan kompetitif, maka diperlukan suatu usaha dengan dunia industri untuk menyesuaikan keterampilan yang fleksibel dan dinamis agar mampu mengembangkan keahlian yang lebih berkualitas. Selain itu, berkembangnya teknologi menyebabkan munculnya sarana dan peralatan yang lebih efisien dan efektif, sehingga masyarakat dapat memperoleh pelayanan yang lebih baik.

Oleh karena itu, SMK Negeri 27 Jakarta menjalin kerja sama dengan dunia industri yang berkembang dalam mengimplementasikan ilmu yang diperoleh para siswa selama di bangku sekolah, serta meningkatkan wawasan para siswa berkaitan dengan kebutuhan masyarakat.

Bentuk kerja sama antara SMK Negeri 27 Jakarta dengan dunia industri berupa penerapan Pendidikan Sistem Ganda yang merupakan momentum untuk mereformasi secara menyeluruh dalam upaya memberikan penerapan pengembanan usaha yang bermuara pada peningkatan mutu. Sebagai lembaga pendidikan, merupakan wujud nyata dari persepsi bahwa masyarakat merupakan inti dari prioritas utama dalam pelayanan.

SMK Negeri 27 Jakarta merupakan salah satu lembaga pendidikan yang tersusun dalam bentuk struktur organisasi yang dimaksudkan untuk memudahkan pelaksanaan tugas-tugas guna memperlancar proses dalam menerapkan pencapaian tujuan. Maksud dari pelaksanaan tugas adalah untuk menghindari ketimpangan atau tumpang tindih antara pekerjaan dengan kegiatan belajar yang dilakukan oleh para siswa sebagai Prakerin di dunia industri yang berada di masyarakat. Sebagai peserta Prakerin siswa akan tetap berusaha menyesuaikan diri dan menyelesaikan tugas yang diberikan sesuai dengan keterampilan dan tetap berusaha menjaga kelancaran proses kerja, serta menjaga kualitas dari pekerjaannya.

Bertitik tolak dari kondisi persaingan di dunia industri dewasa ini dan upaya mengimplementasi- kan ilmu yang diperoleh para siswa selama di bangku sekolah, serta meningkatkan wawasan siswa berkaitan dengan dunia kerja, diperlukan kerja sama yang mampu memberikan dukungan secara maksimal terhadap pelaksanaan Praktik industri. Oleh karena itu, dirasa perlu untuk mengetahui seberapa besar dukungan dunia industri terhadap pelaksanaan Prakerin terutama di SMK 27 Jakarta.

Berdasarkan latar belakang di atas pada penelitian ini dirumuskan permasalahan sebagai berikut: Bagaimana daya dukung dunia industri terhadap pelaksanaan prekerin di SMKN 27 Jakarta? Dari rumusan masalah tersebut dikembangkan beberapa pertanyaan pokok penelitian sebagai berikut 1) Bentuk-bentuk dukungan seperti apa yang diberikan Industri terhadap pelaksanaan Prakerin siswa SMK?; 2) Bagaimana gambaran pelaksanaan prakerin di Industri mitra SMK 27 Jakarta?

Mengacu pada permasalahan tersebut di atas, penelitian ini bertujuan untuk mengetahui bentuk-bentuk dukungan Industri Mitra SMK 27 Jakarta terhadap Pelaksanaan Program Prakerin.

\section{Kajian Literatur}

\section{Link \& Match}

Dalam era globalisasi dan informasi, kemampuan SDM dalam penguasaan bisnis dan Iptek bukan hanya merupakan kebutuhan, bahkan sudah menjadi keharusan apabila bangsa Indonesia ingin berperan dalam persaingan global, bahkan persaingan regional ASEAN Free Trade Area (AFTA) misalnya yang sudah dimulai tahun 2002 sudah selayaknya harus segera disikapi dengan upaya percepatan peningkatan "kualitas SDM Indonesia" melalui peningkatan mutu, relevansi dan daya saing pendidikan.

Peningkatan mutu, relevansi dan daya saing pendidikan digunakan pendekatan komperehensif didesain berdasarkan isi Undang-Undang RI Nomor 20 tahun 2003, yang mengamanatkan agar dikembangkannya Standar Nasional Pendidikan (SNP) dan diberlakukannya otonomi yang cukup luas kepada satuan pendidikan. SNP dituangkan dalam PP No 19 tahun 2005, tentang Standar Nasional Pendidikan. PP 19 tahun 2005 mengamanatkan dibentuknya Badan Standar Nasional Pendidikan (BSNP) dengan tugas utama 
mengembangkan 8 SNP, yaitu: 1) Standar Isi, 2) Standar Kompetensi Lulusan, 3) Standar pendidik dan Tenaga kependidikan, 4) Standar sarana dan prasarana, 5) Standar Penilaian, 6) Standar proses, 7) Standar pengelolaan, dan 8) Standar Biaya.

Dengan mengacu kedelapan standar tersebut diharapkan relevansi dan daya saing lulusan satuan pendidikan akan meningkat. Relevansi pendidikan berarti bahwa sistem pendidikan perlu disesuaikan agar berbagai kebutuhan masyarakat, seperti kebutuhan peserta didik, kebutuhan keluarga, dan kebutuhan dunia kerja termasuk dunia usaha dan industri dapat dipenuhi. Idealnya semua kebutuhan masyarakat dapat diidentifikasi dengan baik dan penyelenggaraan pendidikan diarahkan untuk meningkatkan kualitas hingga dapat memenuhi berbagai kebutuhan tersebut. Karena kebutuhan masyarakat sangat beragam maka perlu ditentukan manakah di antara kebutuhan dan kepentingan itu yang menjadi prioritas pada suatu kurun waktu tertentu. Pada pengembangan pendidikan teknologi dan kejuruan Pemerintah memprioritaskan relevansi pendidikan pada kebutuhan dunia kerja melalui kebijaksanaan link \& match.

Konsep link \& match merupakan salah satu bentuk penyelengaraan pendidikan yang berorientasi pada dunia kerja. Link \& match berarti ada keterkaitan kuat dan kesepadanan antara kompetensi lulusan lembaga pendidikan dengan kualifikasi dan kompetensi yang dibutuhkan dunia kerja. Link secara harfiah berarti terkait, menyangkut proses yang harus interaktif, dan match berarti cocok, meyangkut hasil yang harus sesuai atau sepadan (Dedy Supriadi, 2002:231). Link menunjuk pada suatu proses kolaborasi, yaitu bahwa proses pendidikan selayaknya melibatkan semua pihak terkait terutama pihak pengguna, sehingga hasilnya pun cocok (match) dengan kualitas yang dibutuhkan dunia kerja, konsep link \& match merupakan supply-demand dalam arti luas, yaitu dunia pendidikan sebagai penyiap SDM, individu, masyarakat, serta dunia kerja/industri sebagai pihak yang membutuhkan dan menyerap para lulusan.

Dalam mengantisipasi percepatan AFTA maka yang menjadi topik bukanlah hanya sekedar pendekatan strategis apakah sistem kolaborasi antara dunia pendidikan dan industri ini dapat diterapkan atau mustahil diwujudkan di Indonesia, namun yang perlu dilakukan saat ini adalah implementasi segera program-program kemitraan dalam rangka meningkatkan kualitas maupun kuantitas SDM yang terlibat di dalamnya. Program Link \& Match (keterkaitan \& kesepadanan) antara dunia Pendidikan dengan Dunia usaha/Industri merupakan wahana strategis dan bentuk upaya nyata untuk mewujutkan dan membangun "suasana sinergis" antara lembaga pendidikan, lembaga penelitian, dunia riset dan dunia Usaha/ Industri sebagaimana terlihat pada skema Gambar 1.

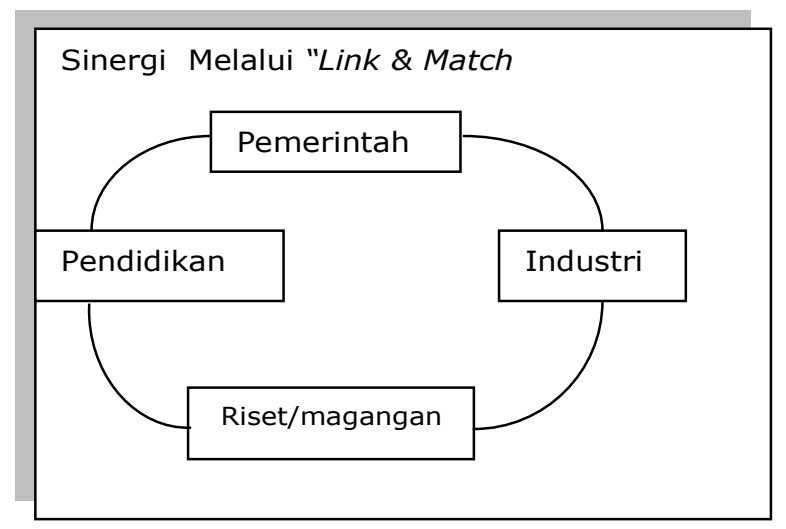

Sumber: Anshori Zauzal (2004)

Gambar 1 Skema Link \& Match.

Skema tersebut menunjukkan bahwa Pemerintah sebagai pemegang kebijakan dapat menjembatani kerja sama antara lembaga pendidikan dan Industri. Demikian juga lembaga pendidikan bersama-sama industri dapat berkolaborasi dalam menyelengarakan riset dan pengembangan SDM untuk kebutuhan Industri.

Dengan demikian, untuk menghasilkan kualitas SMK baik proses maupun keluaran diperlukan implementasi link and match antara sekolah dengan dunia usaha dan dunia industri (DUDI) secara bertahap dan berkesinambungan baik dalam bentuk kerjasama penelitian maupun permagangan. Pendidikan dikatakan berkualitas jika proses belajar-mengajar berjalan dengan baik dan menghasilkan produk yang berkualitas. Dalam hal ini, efesiensi pendidikan mempunyai arti bahwa proses pendidikan mencapai hasil yang maksimal dengan biaya yang wajar. Dalam pandangan yang lebih luas, efesiensi berkaitan dengan profesional- 
isme dalam manajemen pendidikan yang di dalamnya mengandung disiplin, kesetiaan, keahlian, dan etos kerja.

Dalam implementasinya Link \& Match berpegang dan berpedoman pada peran masingmasing pihak, yaitu Pemerintah, lembaga pendidikan dan Industri, yang sering disebut sebagai segitiga teknologi, yaitu: lembaga pendidikan, mempunyai tugas menyiapkan peserta didik menjadi masyarakat yang memiliki kemampuan akademik dan/atau profesional disamping pengembang ilmu pengetahuan dan teknologi. Dunia Industri diperlukan sebagai jalur ke mekanisme pasar sekaligus penyerap SDM dan pengguna kemampuan Iptek.

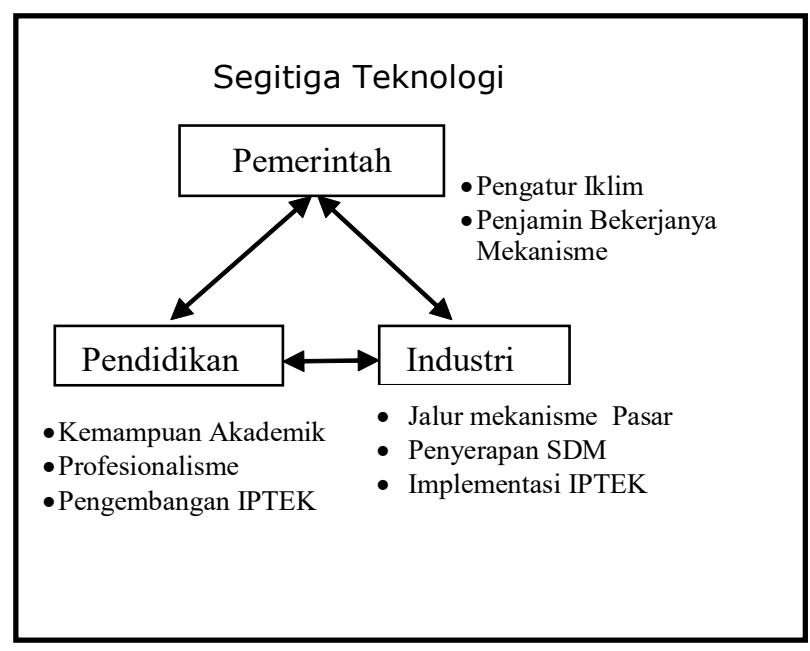

Sumber: Anshori Zausal (2004)

\section{Gambar 2. Segitiga teknologi}

Pemerintah dalam hal ini akan berperan sebagai pengatur iklim dan penjamin bekerjanya mekanisme segitiga teknologi tersebut. Pemerintah dapat menggunakan berbagai cara untuk mendorong indutri agar berperan serta dalam pelatihan.

Dengan demikian, dapat disimpulkan bahwa konsep link \& match merupakan program Tripartit, yaitu: pemerintah, lembaga pendidikan dan dunia usaha/Industri untuk melakukan kolaborasi dalam meningkatkan kualitas lulusan Sekolah menengah Kejuruan (SMK) sehingga terjadi kecocokan atau kesesuaian dengan kebutuhan masyarakat termasuk dunia Usaha dan Industri.

\section{Pendidikan Sistem Ganda}

Khusus untuk Sekolah Menengah Kejuruan (SMK), strategi pokok dalam rangka operasionalisasi link
\& match sebagai suatu kebijakan Depdikbud, adalah Pendidikan Sistem Ganda (PSG). PSG merupakan suatu bentuk pelatihan profesional yang secara sistematik mengkombinasikan dan menya-tukan program pendidikan di sekolah dan program keahlian yang diperoleh melalui aktifitas kerja langsung di tempat kerja. Hal ini diarahkan dan ditujukan untuk mendapatkan keterampilan profesional tertentu (http://www.hamline.edu/ apakabar /basisdata/1997/02/16/0012.html).

Program pendidikan pada PSG diarahkan pada pencapaian kemampuan profesional sesuai dengan tuntutan jabatan-pekerjaan yang berlaku di lapangan kerja. Menurut Jerlin Papahan (2002) dalam Dedi Supriadi (2002) bahwa: Pendidikan Sistem Ganda merupakan suatu bentuk penyelenggaraan pendidikan keahlian profesional, yang memadukan secara sistematik dan sinkron antara pendidikan di sekolah dan program penguasaan keahlian yang diperoleh melalui kegiatan bekerja langsung di dunia kerja, dan terarah untuk mencapai suatu tingkat keahlian profesional tertentu: Dengan demikian, PSG merupakan suatu proses pendidikan yang melibatkan sekolah di satu sisi dan dunia kerja pada sisi lain. PSG mempunyai beberapa tujuan, yaitu: 1) Menghasilkan tenaga kerja yang memiliki keahlian berkualitas; 2) Memperkokoh Link dan Match antara SMK dan Dunia industri; 3) Meningkatkan efisiensi proses pendidikan dan pelatihan tenaga kerja yang berkualitas;4) Memberi pengakuan dan pernghargaan terhadap pengalaman kerja sebagai bagian proses pendidikan. (Dedy Supriyadi, 2002).

Pada prinsipnya dalam implementasi konsep PSG, siswa belajar teori di sekolah dan belajar praktik sebagian di dunia usaha dan dunia industri (DUDI). Dasar dari PSG adalah pendidikan kejuruan yang mem-persiapkan siswa agar dapat bekerja di bidang tertentu; dengan kata lain SMK dituntut untuk terus berkembang seiring dengan tuntutan peningkatan bisnis dan industri

PSG memberikan pengalaman kerja di bidang industri dalam rangka training kerja di bidang industri. Melalui training, rasa tanggung jawab, sikap, disiplin, hubungan sosial, etika, dan tuntutan dunia kerja ditanamkan. Pengalaman praktek kerja, keterampilan terpadu. Dalam sikap produktif membentuk PSG. 
PSG merupakan suatu bentuk pelatihan profesional yang secara sistematik mengkombinasikan dan menyatukan program pendidikan di sekolah dan program keahlian yang diperoleh melalui aktifitas kerja langsung di tempat kerja. Hal ini diarahkan dan ditujukan untuk mendapatkan ketrampilan profesional tertentu.

Program pendidikan pada PSG diarahkan pada pencapaian kemampuan profesional sesuai dengan tuntutan jabatan-pekerjaan yang berlaku di lapangan kerja. Program pendidikan ini dapat tercapai jika ada kerja sama yang saling membutuhkan antara dunia pendidikan khususnya Sekolah Menengah Kejuruan (SMK) dan dunia kerja. Tanpa peran serta dunia kerja dalam pendidikan maka untuk mencapai kemampuan profesional tidak akan tercapai, karena hanya

Bertolak dari besarnya peran dunia kerja, maka kesuksesan Sekolah Menengah Kejuruan sangat dipengaruhi oleh keberhasilan dalam melakukan kerja sama dengan dunia industri dan dunia usaha. Lingkup kerja sama ini meliputi peren-canaan, pelaksanaan, evaluasi, dan pemasaran tamatan. Perencanaan pendidikan dalam PSG dimulai dengan penyusunan kurikulum bersama antara pihak sekolah dengan pihak perusahaan pasangan.

Dalam penyusunan kurikulum perlu memperhatikan lima komponen berikut: 1) Komponen Pendidikan Umum (normatif), dimaksudkan untuk membentuk peserta didik menjadi warga negara yang baik; 2) Komponen Pendidikan Dasar Penunjang (adaptif), untuk memberi bekal penunjang bagi penguasaan keahlian profesi; 3) Komponen Teori Kejuruan, untuk membekali pengetahuan tentang teknis dasar keahlian kejuruan; 4) Komponen Praktik Dasar Profesi, yaitu berupa latihan kerja untuk menguasai teknik bekerja secara baik dan benar; dan 5) Komponen Praktik Keahlian Profesi, yaitu berupa bekerja secara terprogram dalam situasi yang sebenarnya (Depdikbud, 1993:1).

Adapun metode untuk melaksanakan kurikulum yang sudah disusun terdiri atas: 1) Program PSG merupakan program bersama antara SMK dengan dunia kerja/perusahaan pasangannya, sehingga segala sesuatu yang menyangkut penyelenggaraan Sistem Ganda perlu dibicarakan dan disepakati bersama; 2) Komponen
Pendidikan Umum, Pendidikan Dasar Penunjang, dan Teori Kejuruan dilaksanakan sepenuhnya di SMK dan menjadi tanggung jawab SMK; 3 ) Komponen Praktik Dasar Profesi, dapat dilaksanakan di SMK, di dunia kerja/perusahaan pasangan, atau di kedua tempat tersebut, dan menjadi tanggung jawab bersama antara SMK dengan perusahaan pasangannya; 4) Komponen Praktik Keahlian Profesi dilaksanakan di dunia kerja/ perusahaan pasangan, dan sepenuhnya menjadi tanggung jawab perusahaan pasangan; dan 5) Model penyelenggaraan dapat berupa days release, dapat berupa blocks release, dapat berupa hours release, atau kombinasi dari ketiganya.

Dalam penyelenggaraan days release disepakati bersama, dari 6 hari belajar satu minggu, berapa hari di perusahaan dan berapa hari di sekolah. Dalam penyelenggaraan blocks release disepakati bersama bulan/caturwulan/ semester mana di perusahaan, dan bulan/ caturwulan/semester mana di sekolah. Sedangkan dalam penyelenggaraan hours release disepakati jam-jam belajar yang harus dilepas dari sekolah dan dilaksanakan di perusahaan.

Menurut Kemendikbud No $80 / \mathrm{U} / 1993$ tentang kurikulum tahun 1994 SMK: Metode pelaksanaan kurikulum PSG meliputi: 1) Program PSG dijadikan Program bersama antara SMK dengan dunia kerja/ perusahaan pasangannya, sehingga segala sesuatu yang menyangkut penyelenggaraan Sistem Ganda perlu dibicarakan dan disepakati bersama; 2) Program Pendidikan Umum, Pendidikan Dasar Penunjang, dan Teori Kejuruan dilaksanakan sepenuhnya di SMK dan menjadi tanggung jawab SMK; 3) Program Praktik Dasar Profesi, dapat dilaksanakan di SMK, di dunia kerja/ perusahaan pasangan, atau di kedua tempat tersebut, dan menjadi tanggung jawab bersama antara SMK dengan perusahaan pasangannya; 4) Program Praktik Keahlian Profesi dilaksanakan di dunia kerja/perusahaan pasangan, dan sepenuhnya menjadi tanggung jawab perusahaan pasangan; 5) Model penyelenggaraan dapat berupa days release, dapat berupa blocks release, dapat berupa hours release, atau kombinasi dari ketiganya. 


\section{Praktik Kerja Industri (Prakerin)}

Prakerin sebagai bagian dari pendidikan sistem ganda (PSG) pada SMK merupakan bagian dari program bersama antara SMK dan Industri yang dilaksanakan di dunia usaha, industri, program yang dilaksanakan di industri/perusahaan, meliputi: 1) Praktik dasar kejuruan, dapat dilaksanakan sebagian di sekolah, dan sebagian lainnya di industri, apabila industri pasangan memiliki fasilitas pelatihan di industrinya. Apabila industri tidak memiliki fasilitas pelatihan, maka kegiatan praktik dasar kejuruan sepenuhnya dilaksanakan di sekolah; 2) Praktik keahlian produktif, dilaksanakan di industri dalam bentuk "on the job training", berbentuk kegiatan mengerjakan pekerjaan produksi atau jasa (pekerjaan yang sesungguhnya) di industri/ perusahaan sesuai program keahliannya.

Penerapan praktik kerja industri pada pendidikan menengah kejuruan sangat diperlukan untuk mengatasi kesenjangan antara dunia pendidikan dan kebutuhan dunia kerja. Keberhasilan prakerin ini sangat ditentukan oleh: 1) inisiatif dan kreativitas SMK untuk merangkul dunia kerja, serta secara inovatif mengembangkan model pengajaran yang relevan; dan 2) keterbukaan dunia kerja untuk ikut berperan aktif dalam dunia pendidikan,

Dukungan pemerintah melalui undangundang atau peraturan yang memaksa dunia kerja membuka diri terhadap dunia pendidikan, dan Dukungan masyarakat melalui dorongan pada putra-putrinya untuk masuk program Pendidikan Sistem Ganda.

\section{Metodologi Penelitian}

\section{Metode Penelitian}

Metode penelitian yang digunakan adalah survei, di mana penelitian dilakukan papa area populasi baik besar maupun kecil dan data yang diambil adalah data primer yang diperoleh dari hasil wawancara langsung kepada pelaku dalam populasi tersebut (Suharsimi Arikunto, 2002)

\section{Populasi dan Sampling}

Populasi dalam penelitian ini adalah perusahaanperusahaan yang telah bekerja sama dengan SMK Negeri 27 Jakarta dalam proses penerapan program Prakerin dan memilih secara acak \{random) jumlah sampel sebanyak 20 (dua puluh) perusahaan dari populasi yang ada.

\section{Instrumen penelitian}

Instrumen yang digunakan dalam penelitian ini adalah kuisioner yang berisi pertanyaan tentang daya dukung dunia industri terhadap pelaksanaan prakerin siswa SMKN 27 Jakarta.

\section{Teknik Pengumpulan Data}

Teknik pengumulan data dalam penelitian ini adalah dengan melakukan wawancara, yakni dengan dengan pertanyaan-pertanyaan berkaitan dengan materi penelitian yang bersifat tertutup dan terbuka bagi responden.

\section{Teknik Analisis Data}

Dalam menganalisis data yang diperoleh, penulis menggunakan metode deskriptif kuantitatif yaitu mengolah data penelitian yang diperoleh dari sampel dan diolah menggunakan SPSS 15 secara statistik berupa angka-angka kemudian diungkapkan secara deskriptif maksud dari angka-angka tersebut sehingga dihasilkan kesimpulan dari penelitian ini,

\section{Hasil penelitian dan pembahasan \\ Deskripsi Data}

\section{Jenis Usaha Perusahaan}

Dari 20 responden yang diwawancarai jenis usaha apa yang menjadi tempat prakerin, 35\% diantaranya adalah dari jenis usaha salon, $20 \%$ adalah hotel dan $10 \%$ adalah apartemen dan lainlain (garmen) serta $5 \%$ dari bidang usaha catering dan spa.

\section{Jenis Usaha}

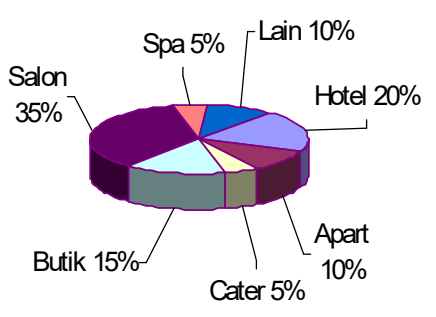

Gambar 3. Jenis 2 Usaha Perusahaan Mitra 


\section{Industri memiliki Program Prakerin}

Pada poin apakah industri sampel dimana responden berkerja, memiliki program kerja tetap untuk kegiatan prakerin, dari 20 responden yang diwawancarai $85 \%$ menjawab ada (memiliki) program kerja untuk prekerin, $10 \%$ belum ada dan $5 \%$ tidak ada.

\section{Frekuensi penerimaan Peserta Prakerin}

Pada poin berapa kali responden menerima peserta prakiran dalam setahun, dari 20 responden yang diwawancarai $65 \%$ menjawab lebih dari 5 (lima) kali dalam setahun meneriman peserta prakiran, $20 \%$ menjawab 2 (dua) kali, dan $10 \%$ menjawab 4 (empat) kali serta $5 \%$ menjawab 3 (tiqa) kali.

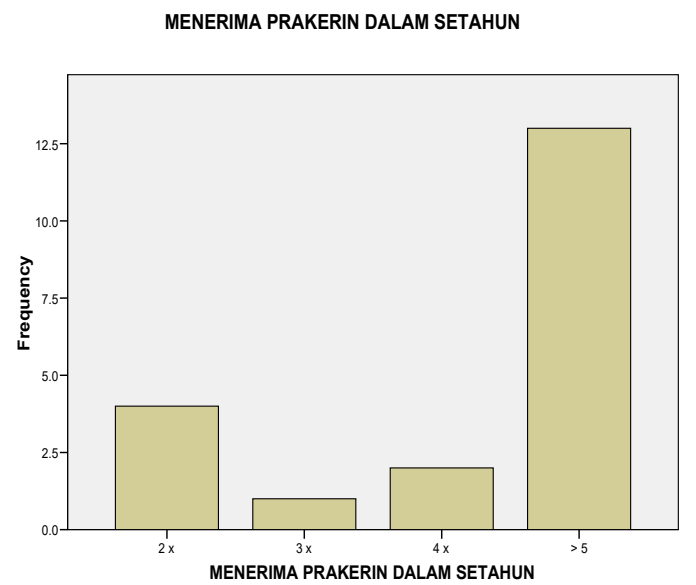

Gambar 4. Grafik Frekuensi Penerimaan Siswa Prakerin

Gambar 4 menunjukkan bahwa sebagian besar Industri menerima siswa Prakerin lebih dari 5 kali dalam satu tahun

\section{Mekanisme rekrutmen}

Pada poin tentang apabila responden memerlukan siswa prakerin, apakah selalu menghubungi pihak SMKN 27 Jakarta, dari 20 responden yang diwawancarai $65 \%$ menjawab selalu menghubungi pihak sekolah (SMKN 27 Jakarta), $15 \%$ menjawab jarang dan $10 \%$ menjawab tidak pernah dan lain-lain.

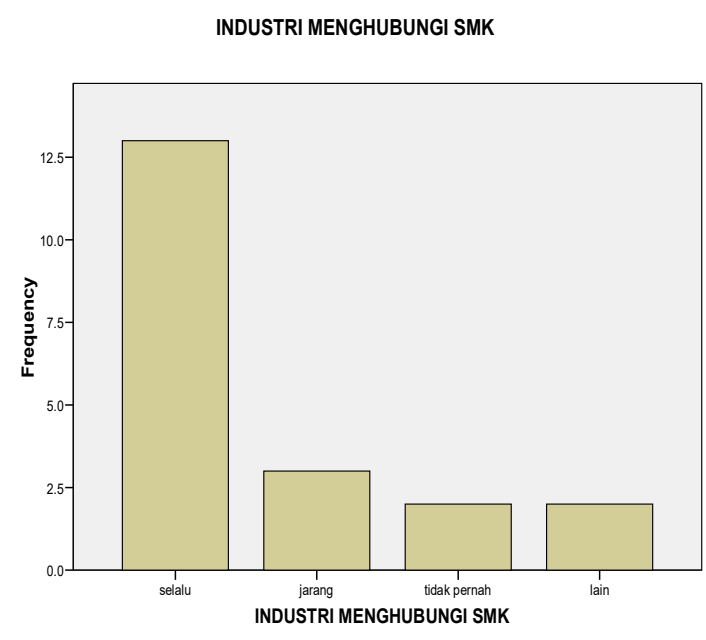

Gambar 5. Inisiatif Industri menghubungi Sekolah

Sebagaian besar Sekolah mitra SMK 27 Jakarta Berinisiatif menginformasikan lowongan prakerin kepada Sekolah.

Pada butir tentang apabila pihak SMKN 27 Jakarta memerlukan tempat prakerin, apakah mudah menghubungi responden, dari 20 responden yang diwawancarai $50 \%$ menjawab mudah untuk dihubungi, $45 \%$ menjawab sangat mudah, dan $5 \%$ menjawab cukup mudah.

\section{Tes calon peserta Prakerin}

Pada poin apakah setiap pelaksanaan prakerin selalu menggunakan tes penyaringan awal bagi calon peserta, dari 20 responden yang diwawancarai $30 \%$ menjawab selalu dan jarang melakukan tes penyaringan awal bagi calon peserta prakerin, $20 \%$ menjawab tidap perlu dan jika perlu saja.

\section{Pengumuman kelulusan tes Pra Prakerin}

Pada butir apakah industri tempat responden bekerja selalu menghubungi secepatnya ke pihak SMKN 27 Jakarta untuk menginformasikan peserta prakerin yang lulus dan berhak ikut prakerin, dari 20 responden yang diwawancarai $65 \%$ menjawab selalu menghubungi pihak sekolah, 20\% menyatakan jarang dan $15 \%$ menyatakan tidak pernah.

\section{Pelaksanaan Prakerin}

\section{Menempatkan siswa sesuai bidang keahlian}

Pada poin apakah industri tempat responden bekerja menempatkan siswa prakerin sudah 
sesuai dengan bidang keahlianya, dari 20 responden yang diwawancarai $65 \%$ menyatakan sudah menempatkan peserta prakerin sesuai dengan bidang keahlianya, 30\% menyatakan sangat sesuai dan $5 \%$ menyatakan cukup sesuai.

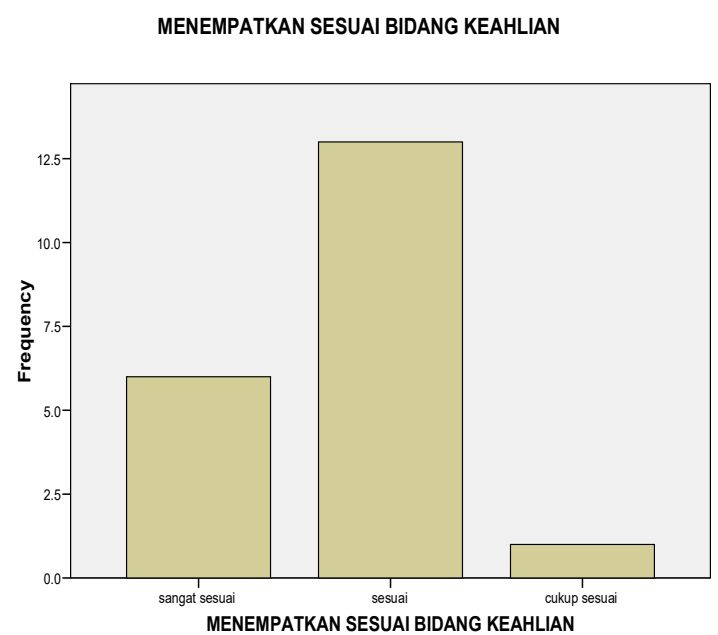

Gambar 6. Grafik Indutri Yang Menepatkan siswa Sesuai Bidang Studinya

Gambar 6 menunjukkan data apakah industri tempat responden bekerja menempatkan siswa prakerin sudah sesuai dengan bidang keahlianya yang ditampilkan dalam bentuk grafik. Sebagaian besar $(65 \%)$ responden menyatakan sudah menempatkan siswa Prakerin sesuai dengan bidangnya bahkan sebagian sudahmenyatakan sangat sesuai hanya sebagian kecil yang menyatakan cukup sesuai.

\section{Pemberian bimbingan kepada peserta prakerin}

Pada poin apakah industri tempat responden bekerja memberikan bimbingan terhadap peserta prakerin, dari 20 responden yang diwawancarai 95\% menyatakan selalu memberikan bimbingan kepada peserta prakerin, $5 \%$ menyatakan jarang.

\section{Memberi kesempatan bekerja sendiri}

Pada poin apakah industri tempat responden bekerja memberi kesempatan kepada peserta prakerin untuk melaksanakan pekerjaannya sendiri, dari 20 responden yang diwawancarai $75 \%$ menyatakan selalu memberi kesempatan kepada peserta prakerin untuk melaksanakan pekerjaannya sendiri, 25\% meyatakan tidak selalu.

\section{Meminjamkan fasilitas kerja}

Pada point apakah industri tempat responden bekerja memberi pinjaman fasilitas kepada peserta prakerin berupa loker, pakaian kerja dan sebagainya, dari 20 responden yang diwawancarai $75 \%$ menyatakan selalu memberi pinjaman fasilitas kepada peserta prakerin berupa loker, pakaian kerja dan sebagainya dan $25 \%$ menyatakan jarang. menunjukkan data apakah industri tempat responden bekerja memberi pinjaman fasilitas kepada peserta prakerin berupa loker, pakaian kerja dan sebagainya yang ditampilkan dalam bentuk grafik

\section{Evaluasi Prakerin}

Pada point apakah industri tempat responden bekerja mengadakan eveluasi kegiatan pelaksanaan prakerin, dari 20 responden yang diwawancarai $75 \%$ menyatakan selalu mengadakan eveluasi kegiatan pelaksanaan prakerin dan $25 \%$ menyatakan cukup.

\section{Keterlibatan Pimpinan Industri}

Pada poin ini apakah pimpinan tempat responden bekerja mendukung program prakerin, dari 20 responden yang diwawancarai $60 \%$ menjawab sangat mendukung program prakerin sedangkan $40 \%$ menjawab mendukung program prakerin.

\section{Mengizinkan sekolah memonitor pelaksanaan Prakerin di Industri}

Pada point apakah industri tempat responden bekerja memberi izin kepada pihak SMKN 27 Jakarta untuk melaksanakan monitoring peserta, dari 20 responden yang diwawancarai 95\% menyatakan selalu memberi izin kepada pihak SMKN 27 Jakarta untuk melaksanakan monitoring peserta dan $5 \%$ menyatakan tidak pernah.

\section{Siswa mengikuti seluruh kegiatan perusahaan}

Pada point apakah dalam pelaksanaan prakerin industri tempat responden bekerja memberi kesempatan kepada peserta untuk dapat mengikuti seluruh kegiatan yang ada di industri, dari 20 responden yang diwawancarai 55\% menyatakan selalu memberi kesempatan kepada peserta untuk dapat mengikuti seluruh kegiatan yang ada di industri tempat responden bekerja dan $45 \%$ sisanya menyatakan cukup. 


\section{Memberi tindakan atas pelanggaran siswa}

Pada poin apakah industri tempat responden bekerja memberi tindakan terhadap peserta prakerin jika melakukan kesalahan baik berupa teguran sampai pemberhentian, dari 20 responden yang diwawancarai $70 \%$ menyatakan selalu memberi tindakan terhadap peserta prakerin jika melakukan kesalahan dan 30\% menyatakan cukup.

\section{Memberikan Sertifikat}

Pada poin apakah industri tempat responden bekerja memberi sertifikat bagi siswa setelah mereka menyesaikan kegiatan prakerin, dari 20 responden yang diwawancarai $85 \%$ menyatakan selalu memberi sertifikast bagi siswa setelah mereka menyesaikan kegiatan prakerin dan $15 \%$ nyatakan tidak pernah.

Berdasarkan hasil wawancara dari 20 responden, mayoritas jenis usaha yang menjadi tempat prakerin adalah jasa salon (35\%) dan frekuensi peserta prekerin yang diterima responden dalam setahun adalah lebih dari 5 kali (65\%). Pada aspek komunikasi, 65\% responden menyatakan akan selalu menghubungi pihak SMKN 27 Jakarta jika memerlukan siswa prakerin dan $50 \%$ responden menyatakan bahwa pihaknya mudah dihubungi jika pihak SMKN 27 Jakarta memerlukan tempat prakerin. Pada aspek program, $85 \%$ responden menyatakan perusahaannya telah memiliki program kegiatan khusus untuk peserta prakerin, pada aspek dukungan $60 \%$ responden menyatakan bahwa pimpinan mereka sangat mendukung kegiatan prakerin yang mere adakan.

Pada aspek prosedur pelaksanaan, 30\% responden menyatakan selalu dan jarang melakukan ujian tes seleksi bagi calon peserta prakerin dan $65 \%$ responden menyatakan selalu menghubungi secepatnya ke pihak SMKN 27 Jakarta untuk menginformasikan peserta prakerin yang lulus dan berhak ikut prakerin, serta $85 \%$ responden menyatakan selalu memberi sertifikast bagi siswa setelah mereka menyesaikan kegiatan prakerin

Pada aspek pelaksanaan prakerin, 95\% responden menyatakan selalu memberikan bimbingan terhadap peserta prakerin, 65\% responden menyatakan telah menempatkan siswa prakerin sudah sesuai dengan bidang keahlianya, $75 \%$ responden menyatakan selalu memberi kesempatan kepada peserta prakerin untuk melaksanakan pekerjaannya sendiri, 75\% responden menyatakan selalu memberi pinjaman fasilitas kepada peserta prakerin berupa loker, pakaian kerja dan sebagainya, 75\% responden menyatakan selalu mengadakan eveluasi kegiatan pelaksanaan prakerin, dan 95\% responden menyatakan selalu memberi izin kepada pihak SMKN 27 Jakarta untuk melaksanakan monitoring peserta, serta $55 \%$ responden menyatakan selalu memberi kesempatan kepada peserta untuk dapat mengikuti seluruh kegiatan yang ada di industri tempat responden bekerja.

\section{Pembahasan}

SMKN 27 Jakarta telah terjalin komunikasi yang baik dengan dunia industri (responden), hal tersebut ditunjukkan dari upaya perusahaan untuk menghubungi sekolah jika memerlukan peserta prakerin dan kemudahan pihak sekolah menghubungi perusahaan pada saat membutuhkan tempat prakerin.

Pelaksanaan prakerin selama ini telah diprogramkan dengan baik oleh perusahaan dan mendapat dukungan penuh dari pimpinan di masing-masing perusahaan yang menjadi tempat pelaksanaan prakerin. Ditinjau dari Prosedur pelaksanaan prakerin masih dianggap perlu dilakukan perbaikan, hal tersebut terindikasi dari masih sedikitnya perusahaan yang melakukan tes penyaringan awal bagi calon peserta prakerin.

Pelaksaan prakerin telah berjalan dengan baik, hal tersebut terindikasi dari dari adanya bimbingan terhadap peserta prakerin oleh perusahaan. Perusahaan menempatkan siswa prakerin sesuai dengan bidang keahlian, dan memberi fasilitas kepada peserta prakerin berupa loker, pakaian kerja dan sebagainya.

Industri juga mengadakan eveluasi kegiatan pelaksanaan prakerin, dan memberi akses kepada pihak SMKN 27 Jakarta untuk melaksanakan monitoring peserta. Kepada peserta perusahaan mitra memberi kesempatan seluas-luasnya untuk mengikuti seluruh kegiatan yang ada di industri. Dukungan indutri juga nampak pada komitmen pimpinan perusahaan yang memasukan Prakerin 
sebagai program perusahaan dan adanya inisiatif perusahaan menghubungi sekolah, menginformasikan program magang tersebut kepada sekolah serta pemberian bimbingan, pengadaan evaluasi dan pemberian sertifikat oleh Industri.

\section{Simpulan dan Saran}

\section{Simpulan}

Berdasarkan hasil penelitian, dapat disimpulkan sebagai berikut: Sebagian besar pimpinan industri mitra SMK 27 menyatakan sangat mendukung program Prakerin di Perusahaan yang di pimpin.

Bentuk bentuk dukungan yang diberikan Industri untuk siswa Prakerin meliputi: 1) manjadikan Prakerin sebagai program tetap; Sebagai besar industri mitra SMK 27 menerima siswa Prakerin lebih dari 5x (lima kali) dalam setahun; 2) berinisiatif memberikan informasi kesempatan Prakerin kepada Sekolah, 3) Tidak melakukan tes seleksi terhadap calon siswa prakerin.

\section{Pustaka Acuan}

Arikunto, Suharsimi, 2002. Prosedur Penelitian, Suatu Pendekatan Praktek, Yogyakarta: Reneka Cipta.

Anshori Zausal, 2004. Langkah Strategik membangun Kerjasama Tripartit antara Perguruan Tinggi, Pemerintah Daerah dan Industri, Makalah Disampaikan pada SEMIRATA BKS PTK Wilayah barat Bidang Ilmu dan Teknologi, Riau.

Dedi Supriadi, Editor. 2002. Sejarah Pendidikan Teknik dan Kejuruan Di Indonesia. Jakarta: Dikmenjur.

Departemen Pendidikan dan Kebudayaan, 1993. Keputusan Menteri pendidikan Nasional No: 80/U/ 1993 tentang Kurikulum SMK Tahun 1994. Jakarta: Dikmenjur Tahun 1994.

Direktorat Pendidikan Menengah Kejuruan, 1993. Kurikulum Sekolah Menengah Kejuruan Tahun 1994, Landasan Program dan pengembangan. Jakarta: Dikmenjur.

http://www.hamline.edu/apakabar/basisdata/1997/02/16/0012.html Link And Match: Hendaknya Proporsional, Suara Pembaruan Online, 15 Februari 1997.

Undang-Undang Nomor 20 Tahun 2003 tentang Sistem Pendidikan Nasional.

Peraturan Pemerintah Republik Indonesia: Nomor: 19 tahun 2005 tentang Standar Nasional Pendidikan. 